\title{
Decoração e simbolismo das pedras formosas dos balneários-sauna castrejos da Idade do Ferro: leituras possíveis
}

\author{
Decoración y simbolismo de las pedras formosas de los \\ balnearios-sauna castreños de la Edad del Hierro: lecturas \\ posibles
}

\section{Decoration and symbolism of the pedras formosas of the Iron Age sauna-bath: possible readings}

\author{
Maria de Fátima MATOS DA SILVA \\ Universidade Portucalense Infante D. Henrique \\ mfms@upt.pt
}

Fecha de recepción: 15-02-2018

Fecha de aceptación: 30-04-2018

\begin{abstract}
RESUMEN
Los balnearios-sauna castreños del noroeste peninsular son monumentos con horno con una arquitectura muy original, posiblemente asociada a los diversos modelos termales. Se conocen cerca de tres decenas, distribuidos por el noroeste peninsular. La arquitectura compleja de estos monumentos se organiza estructuralmente hacia posibilitar baños de sauna y baños de agua fría. Las dos áreas son divididas por una estela, monolítica, normalmente ornamentada - la pedra formosa.

El papel simbólico que tendrían en el seno de la sociedad castreña de la Edad del Hierro del noroeste peninsular permanece por aclarar y envuelto en gran misticismo, fruto de una posible sacralidad. Este entorno, referido por diversos autores a lo largo de los tiempos, está posiblemente asociado al culto de los dioses de las aguas y a la sacralidad del baño purificador, medicinal, que se refleja en las decoraciones frontales de las pedras formosas, cuya maestría de los escultores que las insculpieran, tipología decorativa, interpretación simbólica y semiótica estudiamos, como objetivos primordiales, a lo largo de este trabajo de investigación.
\end{abstract}

PALABRAS CLAVE: Protohistoria, monumentos con horno, decoración pétrea, interpretación simbólica / semiótica.

\section{ABSTRACT}

The Iron Age sauna-baths of the northwest peninsular are monuments with an oven with very original architecture, possibly associated with the diverse thermal models. There are about three dozen known sauna-baths spread over the northwest peninsular. The complex architecture of these 
monuments is structurally organized to allow for cold water baths and sauna baths. The two areas are divided by a tectiforme stele, monolithic, usually ornamented, known as pedra formosa (beautiful stone).

The symbolic role that they would have had in the heart of the Iron Age "castreña" society in the northwest peninsular remains unclear and shrouded in mysticism, the fruit of a possible sacredness. This environment, referred to by various authors throughout the ages, is possibly associated with the worship of the water gods and the sacredness of the medicinal and purifying bath, which is reflected in the frontal decorations of the pedras formosas, whose masterful sculpting, decorative typology, symbolic interpretation and semiotics we studied as primary objectives of this research work.

KEYWORDS: Protohistory, monuments with oven, stone decoration, symbolic / semiotic interpretation.

\section{INTRODUÇÃO}

Os balneários-sauna castrejos cronologicamente atribuíveis aos finais da Idade do Ferro são monumentos com forno, de construção hipogeia, com uma arquitetura original e complexa. Apesar de possuírem alguma uniformidade construtiva, apresentam uma variedade arquitetónica significativa, associada, provavelmente, a diversos modelos termais. São conhecidos cerca de três dezenas, distribuídos pelo noroeste peninsular, numa área geográfica que abrange o norte da Galiza e das Astúrias e que se prolonga até à margem sul do rio Douro.

Estes balneários-sauna surgem numa época de apogeu da cultura castreja, estando também associados a uma nova estruturação de organização do espaço dos povoados, com um novo ordenamento, proto urbano, organização em "bairros", arruamentos, imponentes muralhas e, sem dúvida, o apogeu da diversidade de expressões artísticas passando pela arte pétrea, relativa à decoração arquitetónica e à escultura de guerreiros, pela proliferação de vasos cerâmicos decorados e pela diversificada e ímpar ourivesaria.

Ao longo dos tempos muita e diversa bibliografia foi editada, debatendo-se qual a sua funcionalidade e cronologia. Dessas publicações faremos uma síntese, acrescentando as publicações mais recentes, como forma de revisão do estado de conhecimento atual.

A revisão bibliográfica apresentada, a distribuição geográfica e a caracterização estrutural dos balneários têm como objetivo contextualizar o trabalho de investigação e não aportar novas teorias interpretativas.

Neste artigo importa-nos, sobretudo, destacar a decoração das estelas frontais -as pedras formosas-, da atual área portuguesa (na medida em que na área espanhola apenas existe uma com motivos decorativos), e analisar a sua simbologia, naturalmente fazendo a inserção no contexto estrutural, a arquitetura dos balneários-sauna, e cultural.

Temos, desta forma, como objetivos principais divulgar, relembrando, um património arqueológico pouco conhecido; sistematizar o conhecimento atual sobre as pedras formosas inseridas na estrutura arquitetónica, e apontar leituras possíveis sobre a interpretação da decoração das pedras formosas (elemento material), tentando conhecer o seu simbolismo (elemento imaterial).

\section{METODOLOGIA E REVISÃO DA LITERATURA}

Em termos metodológicos baseamo-nos na pesquisa bibliográfica e em trabalho de campo de prospeção arqueológica. Há alguns anos estudamos e publicámos artigos sobre 
a decoração arquitetónica castreja (Silva, 1986a) e sobre este tipo de balneários (Silva, 1987) que nos serviram como base, sobretudo pela exaustiva recolha bibliográfica feita nessa época, que mantemos, embora retirando algumas publicações, por, no fundo, serem repetições de opiniões de autores que os precederam, não acrescentando conhecimento. Recentemente, publicamos um outro artigo, com objetivos muito distintos e inserido na problemática do termalismo e da fruição turística (Silva, 2017). Fizemos, pois, a atualização e tratamento do levantamento bibliográfico, bem como do trabalho de campo -com novas deslocações aos povoados onde os balneários se encontram-, tendo sido realizado novo registo fotográfico e levantamento, através de desenho, dos motivos decorativos, com exceção dos que que já havíamos publicado em 1987.

Trocaram-se também ideias com alguns arqueólogos no sentido de saber pormenores sobre cada um dos monumentos e o conhecimento atualizado dos mesmos, dado que alguns permanecem por escavar.

O interesse pelo estudo deste tipo de monumento ocorre pela primeira vez com o aparecimento descontextualizado da Pedra Formosa I da Citânia de Briteiros, no ano de 1723 (Craesbeck, 1726), colocando-se, então, várias hipóteses no sentido de responder às questões sobre o seu significado e a sua utilidade. A explicação mais consensual defendia a posição horizontal da pedra, tendo como função a de ara de sacrifícios (Sarmento, 1904 e 1879/1933; Cartailhac, 1886; Vasconcelos, 1913). Contudo, a posição vertical era também proposta, como fachada de capela funerária (Hübner, 1879/1933) ou como "stella funerária" (Silva, 1876: 136).

Com a descoberta do monumento da Citânia de Briteiros, em 1930, a real utilidade das pedras formosas fica esclarecida, mas, novas interrogações surgem, procurando-se então saber qual a sua função na estrutura à qual estavam associadas.

As opiniões podem ser agrupadas em três teorias interpretativas. A primeira interpretava o monumento como sendo um santuário de culto das águas ou apenas santuário (Sarmento, 1881/1933; Lorenzo, 1948; Jordá, 1969) e a segunda como local de cremação de mortos ou monumento funerário, com implicações simbólico-religiosas (Vasconcelos, 1913; Cabré, 1922; Ribeiro, 1930-34; Santa-Olalla, 1932; Cardozo, 1931-32, 1934, 1946 e 1949; Lorenzo, 1948; Garcia y Bellido, 1968; Romero, 1976; Tranoy, 1981).

A terceira teoria interpretativa, atualmente a que possui maior consenso, adotou diversas designações: edifício com função termal, medicinal ou balneário-sauna (Conde, 1955; Chamoso, 1955; Almeida, 1974 e 1986; Calo, 1993; Silva, 1983, 1983-84 e 1986; Dias, 1997; Ríos, 2000; González, 2006). A esta funcionalidade com um carácter prático associou-se a "envolvência de carácter religioso na prática do banho, salutar e purificador, eventualmente traduzido na simbólica dos motivos representados (...) e ainda mais quando considerados com qualidades medicinais" (Silva, 1986: 60).

A localização em áreas baixas, no limite exterior dos povoados castrejos, próximos de linhas de água ou de nascentes, foram determinantes na sua interpretação funcional, tendo também contribuído para o comprovar outros vestígios de carácter arqueológico encontrados aquando do processo de escavação (Silva, 1986).

Outras interpretações, não sustentadas com evidências arqueológicas, foram também defendidas ao longo dos tempos, como as relacionadas com a utilização industrial do monumento como matadouro (Azevedo, 1946), forno de fundição de metais (Monteagudo, 1952), forno de cerâmica (Fernández, 1953) ou forno de panificação (Júnior, 1966; Gómez, 1980).

Ainda que na última década, sobretudo em Portugal, o estudo sobre estes monumentos tenha estagnado, em Espanha recentemente foram publicados dois artigos de M. Santos Estéves e Marco V. García Quintela (García Quintela e Santos-Estévez, 2015; García 
Quintela, 2016) que pretendem apontar novas interpretações ou pelo menos abrir novos campos de investigação no que concerne à interpretação funcional e social dos balneários. Têm por base diversos estudos, sobre a localização geográfica dos balneários nos diversos povoados, e sobre a iconografia das pedras formosas tentando, desta forma, inseri-las no contexto da história da arte da Idade do Ferro europeia. Marco García Quintela (2016: 109) propõe ainda a hipótese destes balneários serem saunas/útero "se abre el abanico de interpretación de las saunas y se ofrece un ensayo que profundiza algunas propuestas para sugerir que son metáfora material de un útero cuya razón de ser deriva de ideologías y prácticas rituales de tradición indoeuropea".

Outro tema que outrora gerou alguns textos relaciona-se com a cronologia destes balneários variando esta entre a "origem céltica" (Cardozo, 1949: 497) até à época da romanização, "ou até para depois" (Almeida, 1986: 166). Contudo, após a escavação do balneário de Galegos (Barcelos) foi proposta a sua construção para a última fase da cultura castreja (III A [138-136 a. C. a c. 20 a. C.]) mas, com utilização em época romana (Silva, 1986: 60). A maioria dos arqueólogos aceita este intervalo de tempo especificando para cada balneário a cronologia mais plausível, naturalmente, com base no registo arqueológico que interpretaram durante o processo de escavação.

Em resumo, estes primeiros exemplares dos balneários termais foram construídos durante a fase final da Idade do Ferro, perdurando a sua utilização após a chegada dos romanos, dando, assim origem aos primórdios da historiografia do termalismo da Península Ibérica.

Partindo do apriorismo da incapacidade autóctone dos castrejos para elaborarem os motivos geométrico-decorativos, utilizados nos mais diversos utensílios (madeira, pedra, cerâmica ou metais) e, especialmente, os baixos-relevos utilizados na decoração arquitetónica, procuraram-se também várias proveniências para estes motivos decorativos. Podemos dividir as teorias sensivelmente em cinco grupos com origem: na arte egeomicénica (Sarmento, 1882/1933 e 1899; Deonna, 1929); na arte céltica (Garcia y Bellido, 1931; Lopez, 1953); na época da romanização, após o século Il a.C. (Dechelette, 1909; BoshGimpera, 1921; Höck, 1984); após as invasões bárbaras, resultante da ocupação visigótica (Martin, 1881) e origem autóctone, castreja. Esta última atribuível cronologicamente ao espaço de tempo compreendido entre a 2. ${ }^{a}$ Idade do Ferro e a Romanização (Romero, 1976; Calo, 1983; Almeida, 1983 e 1986).

Parece-nos clara a existência de motivos artísticos gravados na pedra com cronologia anterior ao século I d.C., bem como, a presença destes motivos em vários suportes, com simbologia diversa. Existem também paralelos em diversas gravuras rupestres da Idade do Ferro e de cronologias anteriores.

Igualmente se verifica a perduração de diversos motivos (cordiformes, trísceles) em épocas mais recentes, com especial incidência na decoração manifestamente simbólica de capelas e igrejas românicas, por exemplo, do Alto Minho.

Não nos parece, pois, restar dúvidas sobre a criação autóctone dos motivos geométricos decorativos e simbólicos ainda que com influências de vária ordem, seja na Idade do Ferro peninsular e/ou europeia. Contudo, persiste-se em não inserir esta arte decorativa arquitetónica no nordeste peninsular na história da arte europeia (García Quintela e SantosEstévez, 2015), tal como acontece com as esculturas antropomórficas de guerreiros ou as zoomórficas de berrões (Silva, 1988).

\section{DISTRIBUIÇÃO GEOGRÁFICA E ESTUDO ESTRUTURAL DOS BALNEÁRIOS- SAUNA}

Estas estruturas arquitetónicas singulares no âmbito da cultura castreja do noroeste 
peninsular, ao que tudo indica destinadas a banhos-sauna públicos, ressaltam pelo seu aparato e técnica construtiva como monumentos diferentes no seio da arquitetura castreja. Conhecem-se atualmente, pelo menos, referências a trinta e três exemplares sistematizados, por nós próprios (Silva, 1987; 2017) e por outros autores (figura 1). Quinze distribuem-se em área espanhola, e, pelo menos, dezoito exemplares, na área portuguesa que se estende desde o Minho (com a maior concentração) até à margem sul do rio Douro ${ }^{1}$.

Figura 1. Localização e distribuição dos balneários-sauna castrejos conhecidos.

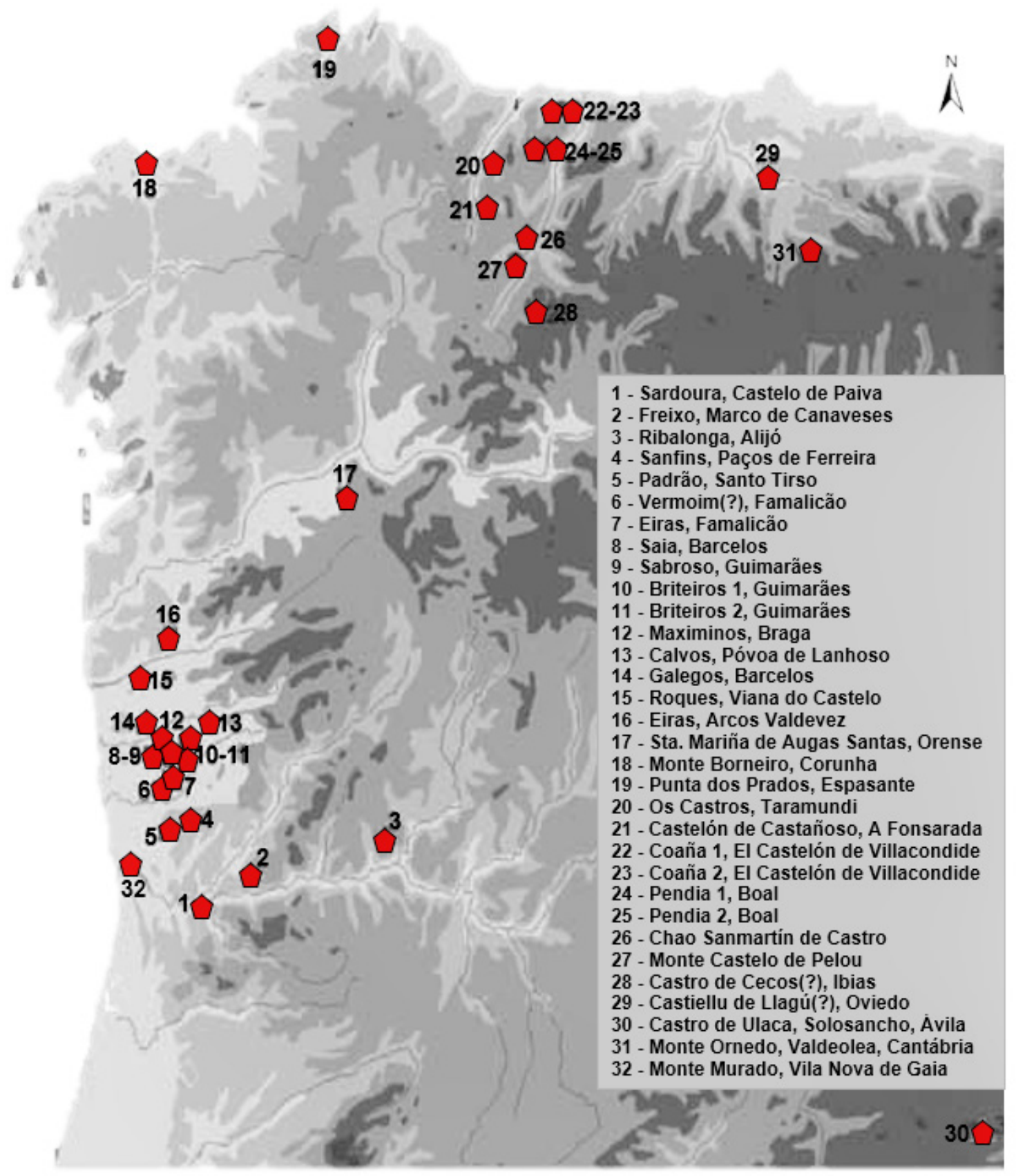

1 Diversas referências bibliográficas de alguns monumentos são muito antigas, com descrições pouco elucidativas, pelo que nos oferecem dúvidas sobre a real existência dos mesmos. Em face disso, optamos por não as mencionar. Igualmente não referimos todos os autores, tendo privilegiado os que primeiro publicaram cada um dos balneários-sauna. 
Nas Astúrias conhecem-se nove situados nos povoados fortificados de Coaña -dois balneários, Coaña 1 e 2- em El Castelón de Villacondide (García y Bellido, 1940; Uría, 1941); Chao Sanmartín de Castro e Monte Castelo de Pelou, ambos em Grandas de Salime (Villa, 1999); Pendia 1 e 2, em Boal (García y Bellido, 1968) e Os Castros, Taramundi (Villa, Menéndez e Fanjul, 2007; Villa, 2012). Castiellu de Llagú, em Oviedo (Berrocal, Martínez e Ruíz, 2002) e Castro de Cecos, Ibias (Villa, 2000) são apresentados como duvidosos na bibliografia que os refere.

$\mathrm{Na}$ Galiza foram estudados quatro localizados nos povoados de Santa Mariña de Augas Santas, Ourense (Lorenzo, 1948); de Monte Borneiro, Corunha (García y Bellido, 1968; Villa, 2012); de Punta dos Prados, em Espasante, Ortigueira, Corunha (Ramil, 199596); e no castro mineiro de Castelón de Castañoso, em A Fonsafrada, Lugo (García Quintela e Santos-Estévez, 2015).

Na província de Castela e León existe um exemplar no Castro de Ulaca, Solosancho, Ávila (Almagro-Gorbea e Álvarez Sanchís, 1993), monumento que se localiza fora da distribuição territorial comummente aceite, tal como o localizado na Cantábria, no oppidum do Monte Ornedo, Valdeolea, Cantábria (Fernández, Mantecón, Callejo e Bolado, 2014). Qualquer deles apresenta diferenças estruturais relativamente aos referidos anteriormente.

A norte do Douro, em território português, foram estudados balneários nos povoados de Santa Maria de Galegos e Monte da Saia, ambos em Barcelos (Silva, 1986); Sabroso (Cardozo, 1976) e Briteiros (dois monumentos), ambos em Guimarães (Ribeiro, 1930-34; Cardozo, 1932 e 1946); Sanfins, Paços de Ferreira (Almeida, 1974); Castelo de Vermoim (Cardozo, 1932) e Alto das Eiras, ambos em Famalicão (Queiroga e Dinis, 2008-2009 estes autores consideram tratar-se do mesmo povoado pelo que se trata apenas de um balneário); Freixo, Marco de Canaveses (Dias, 1997); Calvos, Alto das Quintãs, Póvoa de Lanhoso (Dinis, 2002); na base do monte de Maximinos, em Braga (Lemos, Leite, Bettencourt e Azevedo, 2003); Roques, em Vila Franca, Viana do Castelo (não escavado; Silva e Maciel, 2004); Monte Padrão, Santo Tirso (não escavado; Moreira, 2013) e Eiras, Arcos de Valdevez (Silva e Ferreira, 2016).

A sul do rio Douro existem referências/vestígios destes monumentos no castro de Monte Murado, Vila Nova de Gaia (Aráujo, 1920); Monte do Castro, Sardoura, Castelo de Paiva (Cardozo, 1949); e, no castro de Ribalonga, Alijó, Vila Real (Parente, 2003). Acresce ainda uma pedra formosa que terá sido encontrada no castro de Fontalva, em Elvas (Ferreira, 1966; García y Bellido, 1968).

No que concerne às pedras formosas da atual área portuguesa, são conhecidas apenas onze e uma, na Galiza, como podemos aferir pela Figura 2. Em Portugal temos as de Sardoura, Maximinos, Santa Maria de Galegos, Freixo, Sanfins, Castro de Calvos, Castro do Alto das Eiras (cuja pedra do Castelo de Vermoim também pertenceria a este balneário), Castro de Eiras (Arcos de Valdevez), Briteiros 1 e Briteiros 2, e a hipótese de Fontalva (Ferreira, 1966; García y Bellido, 1968). Por último, Armea, na Galiza. Destas apenas nove (excluindo a hipótese remota de Fontalva) possuem efetivamente decoração, dado que as de Maximinos e Sardoura não apresentam motivos decorativos. 
Figura 2. Localização e distribuição dos balneários-sauna castrejos, conhecidos em Portugal, e das pedras formosas, incluindo-se também a de Armea.

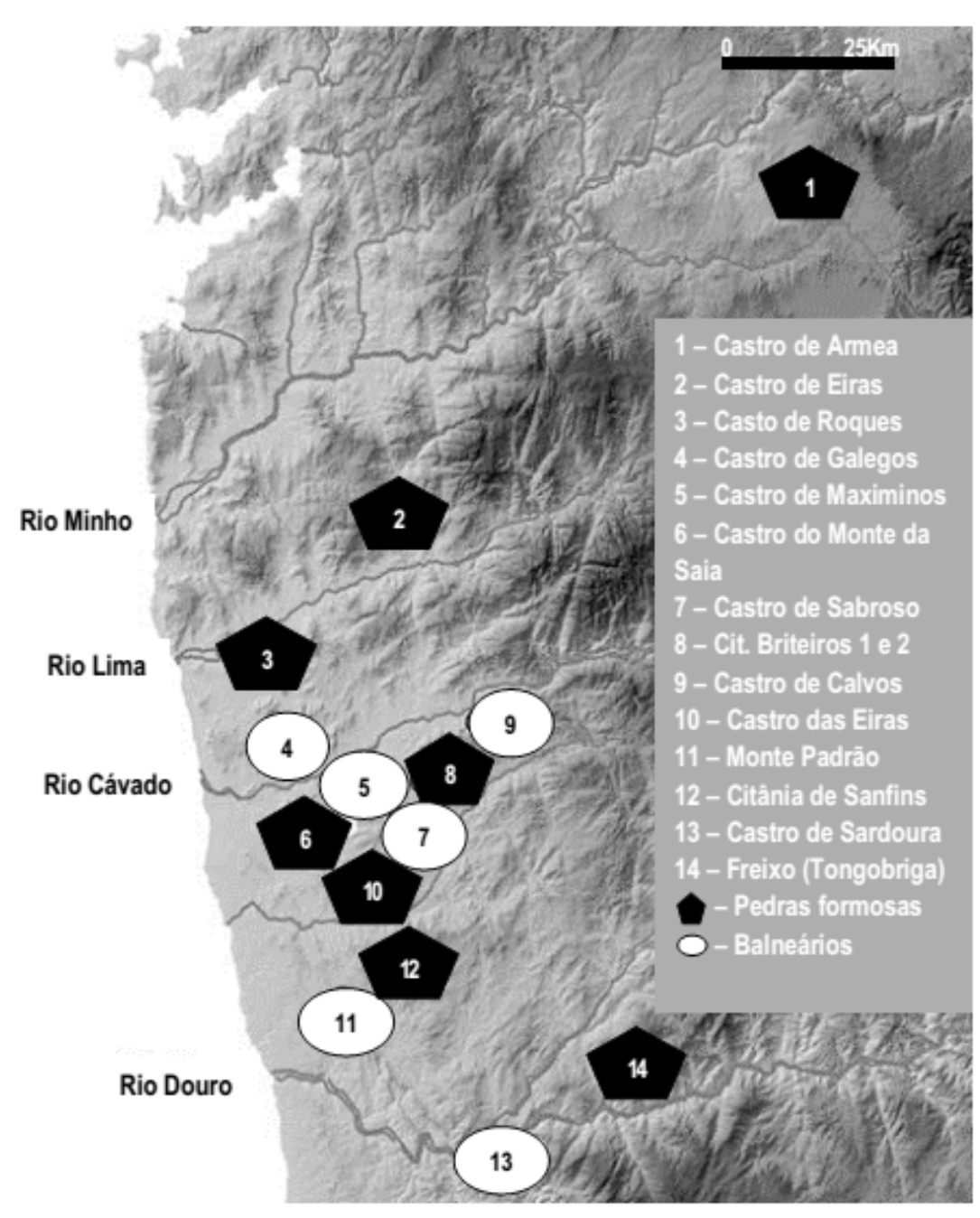

Os balneários-sauna da Idade do Ferro do Noroeste Peninsular possuem um tipo de estrutura com características semelhantes, quer tenham sido construídos em povoados fortificados situados nas Astúrias, quer no Minho, quer na bacia do Douro, mas, também com diversas diferenças que permitem agrupá-los genericamente em núcleos, resultantes da sua situação geográfica e do seu tipo construtivo. Assim, generalizando, existe um grupo entre o rio Douro e o rio Minho, e outro no Norte da Galiza e Astúrias, que alguns autores referem como seguindo o modelo termal bracarense, no primeiro grupo, e modelo termal lucense, no segundo (Ríos, 2000).

O material pétreo utilizado na construção, em granito ou em xisto, é um dos elementos mais marcantes de distinção desses grupos. Não se trata de um elemento cultural, mas relacionado com a geologia do subsolo onde os balneários-sauna foram construídos. Esta determinou a técnica de construção em alvenaria (xisto) ou em grandes monólitos (granito), bem como, a existência de pedra formosa com decoração, apenas nas construídas em granito, e, por fim, a própria planta do monumento. Existem, ainda, estruturas hipogeias, escavadas na rocha, como o caso do monumento do Freixo, que podemos considerar como um terceiro tipo. 
De uma forma geral, os balneários-sauna de construção granítica, relativos ao grupo situado geograficamente entre as bacias hidrográficas do rio Minho e do rio Douro, possuem uma planta organizada em três ou quatro áreas, com funções distintas (figura 3).

Figura 3. Esquema constitutivo de um balneário-sauna com base no alçado do monumento 2 da Citânia de Briteiros (adaptado de Cardoso, 1930).

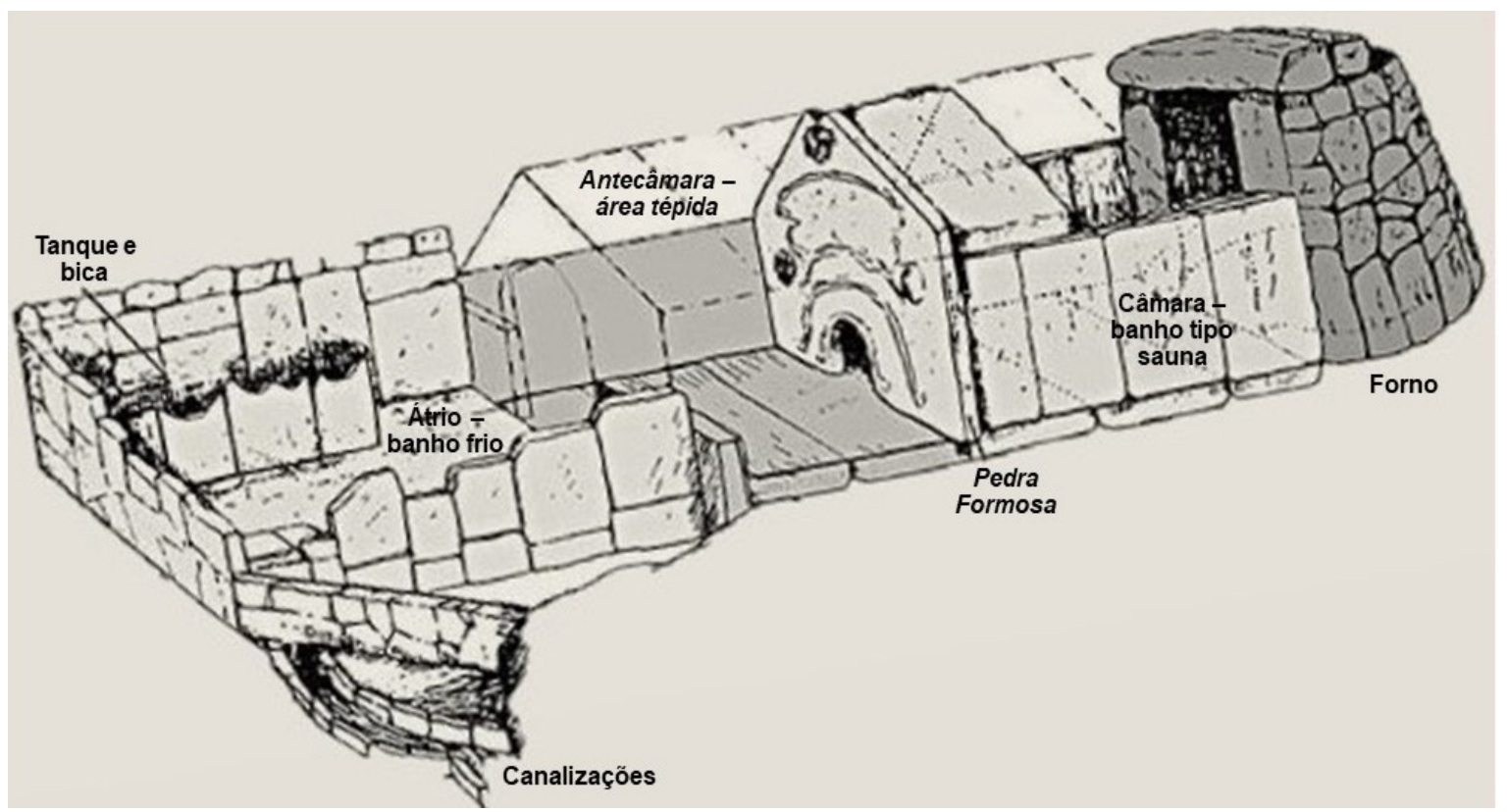

Parte importante do edifício era o forno, com cobertura em falsa cúpula, normalmente de planta circular, semienterrado. A larga porta do forno permitia a passagem do calor e das pessoas para um habitáculo retangular, a câmara, com telhado de dois declives, tendo como parede frontal a pedra formosa. A câmara era utilizada para banhos de tipo sauna, por isso, as lajes eram polidas e bem encaixadas. As pedras da entrada eram também polidas dado que os utilizadores entravam com as costas nuas, voltadas para baixo, pela pequena entrada da pedra formosa. O vapor era produzido pelo lançamento de água em pedras (quartzito, granito, quartzo) que, após aquecidas no forno, eram colocadas na câmara (Silva, 1986).

Estruturalmente as pedras formosas possuem formato tectiforme, com um encaixe lateral, e rasgos que permitem o assentamento do telhado. Possuem, ainda, o referido orifício semicircular, na parte inferior, com pequenas reentrâncias internas e externas (apenas em alguns monumentos) que auxiliam a entrada na câmara na posição horizontal. A exiguidade da abertura ajudava a preservar o calor que o forno lançava na câmara podendo ainda ser tapada. Limitava também o acesso e utilização a pessoas com um porte relativamente delgado e ágil.

Em frente da pedra formosa, a antecâmara e, posteriormente, o átrio com tanque, bica e canalizações para escoar as águas completam a estrutura. O tanque estava associado ao banho frio, ao ar livre, dado que átrio não teria cobertura, bem como, possivelmente, a antecâmara. As paredes e pavimento foram construídos com grandes monólitos. As paredes laterais do tanque apresentam grande desgaste na parte cimeira provocado, possivelmente, pelo aguçar de instrumentos metálicos (como se pode constatar em Briteiros, Saia e Sanfins). 
Estrabão referiu na Geografia (III, 3, 6) que alguns povos que habitam junto do rio Douro tinham hábitos espartanos, dado que se untavam com óleo e tomavam banhos de vapor, produzido através de pedras aquecidas pelo fogo, e, posteriormente, banhos de água fria. Esta descrição foi comprovada pelas diversas escavações arqueológicas e pelo estudo da estrutura construtiva dos balneários-sauna. O fogo no forno ou fornalha

com ventilação pela entrada da câmara e chaminé a ativar a combustão, procedia simultaneamente o aquecimento do ambiente e dos seixos rolados e outras pedras aí colocadas, que eram posteriormente trazidas para o interior da câmara e sobre as quais se lançava água fria para produzir o vapor, que aí se continha, funcionando como uma verdadeira estufa. (...) Melhor explicada fica também a função da antecâmara com a existência dos bancos, a indicar uma maior permanência num local com temperaturas moderadas, uma situação intermédia análoga à do tepidarium das termas romanas. Os banhos de água fria citados por Estrabão seguir-se-iam aos de vapor como nos banhos romanos (...) tendo lugar no átrio, eventualmente por imersão, nos tanques de água corrente (Silva e Maciel, 2004: 122-123).

Normalmente localizam-se na área periférica dos povoados fortificados, topograficamente de menor altitude, perto das cinturas de muralhas, sobretudo, da exterior, junto às vias de acesso e portas. A sua implantação era, pois, determinada pela capacidade de captação e escoamento de água. Estão, assim, sempre associados à existência de água e de caleiras/condutas que a conduzem do poço, fonte ou nascente até ao tanque e bica no átrio, que a retém em depósito. São construções parcialmente soterradas, o que facilitava a canalização de água, e a própria conservação do calor no forno e na câmara. Todos os edifícios deste tipo apresentam uma construção bastante cuidada com existência, em alguns, de elementos decorativos.

\section{AS PEDRAS FORMOSAS: DECORAÇÃO, SIMBOLISMO E ESTUDO SEMIÓTICO}

A decoração da pedra formosa adapta-se, no geral, à sua arquitetura-função, realçando ainda a sua utilidade arquitetónica, ou seja, de entrada e de apoio do telhado.

A temática decorativa pouco diverge da utilizada na decoração das habitações castrejas da fase final da Idade do Ferro. Existe, em alguns casos, uma maior densidade como no caso específico das estelas 1 de Briteiros, de Eiras (Famalicão) e, provavelmente, do Castro de Calvos em que, para além da decoração tectiforme, há um horror ao vazio e uma organização dos motivos diferenciada, justificada pela distribuição espacial dos motivos na estela e funcional, como reflexo da simbólica e da tradição cultural distinta da decoração arquitetónica das cabanas onde habitavam.

Na Tabela 1 ( $A$, B e C), dividida em três por questões gráficas e organizada também com o objetivo da maior compreensão do leitor, sintetizamos os elementos relativos à designação e proveniência das pedras formosas, incluindo plantas esquemáticas dos balneários-sauna e algumas fotografias dos mesmos. Vincando o carácter de divulgação pedagógica e informativa incluímos colunas relativas à imagem da pedra formosa e à sua localização atual, disponibilizando dados que possibilitem ao público a visita aos locais onde as mesmas se encontram. 
Tabela 1A. Diversos elementos sobre os balneários-sauna e as pedras formosas².

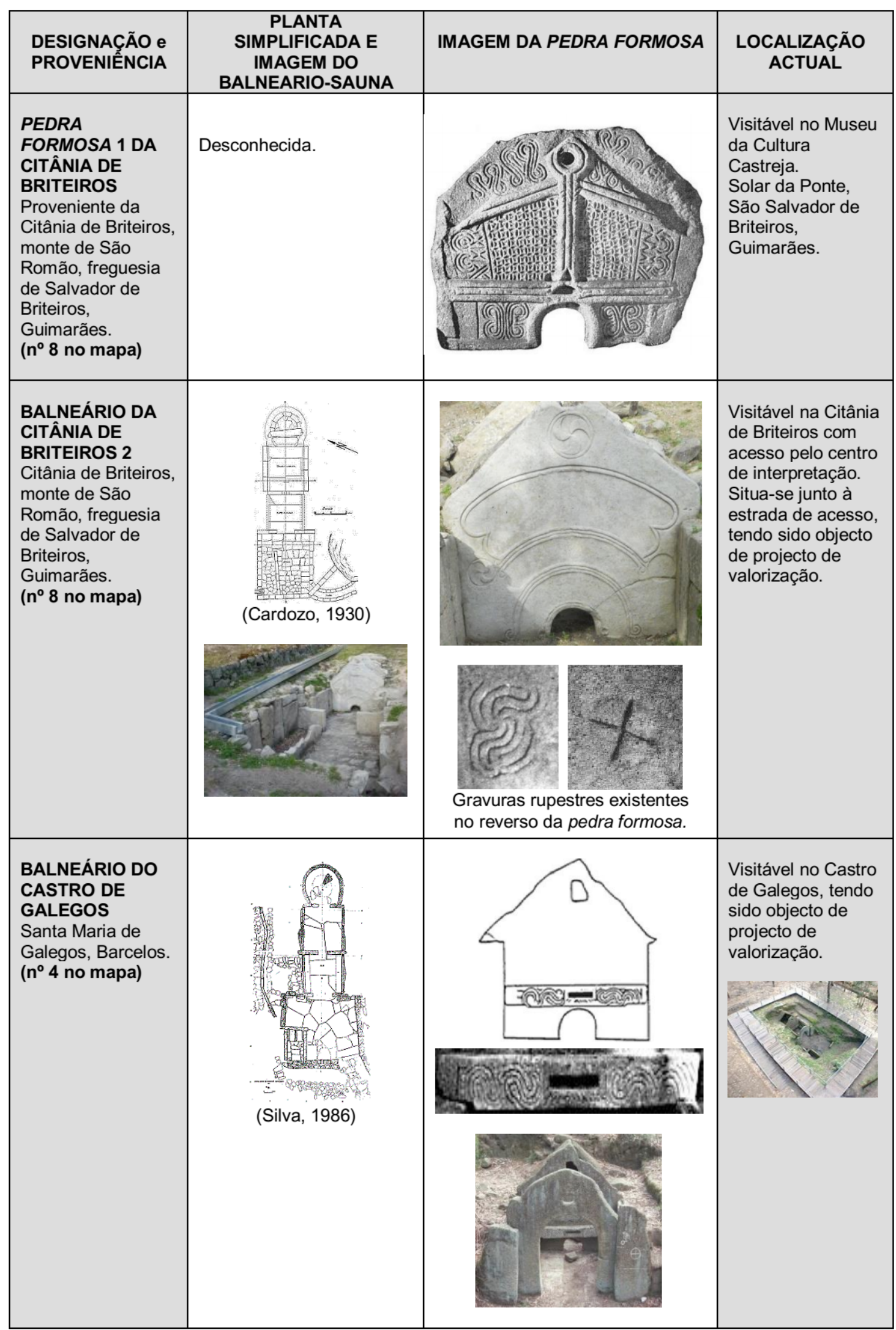

2 A diversidade de escalas e de orientação geográfica impossibilita a inserção deste tipo de informação em todas as plantas, tal como de todas as fontes bibliográficas. Contudo, todos estão citados ao longo do texto. Os desenhos das pedras formosas são de nossa autoria ou dos autores indicados. 
A Pedra Formosa 1 de Briteiros (tabela 1A) possui uma decoração com saliências horizontais, verticais, oblíquas e circulares, cuja organização delimita seis superfícies ornamentadas. Esta decoração em relevo, que divide a estela em várias áreas decorativas, ocorre igualmente nas estelas do Castro do Alto das Eiras (tabela 1A) e de Calvos (tabela 1B).

A esta decoração em relevo, geométrica, acrescem outros motivos, também lineares em forma de linhas diagonais, que se cruzam na zona média lateral, e um quadriculado ou reticulado, central. As linhas cruzadas e semicirculares dispostas lateralmente são o sustentáculo de toda esta decoração, como se esta pedra formosa fosse um compêndio de desenho.

$\mathrm{Na}$ área tectiforme existem vários entrelaçados triangulares ou lanceolados, muito frequentes na decoração de portas da Citânia de Briteiros. O entrelaçado fechado, ladeia a entrada e tem paralelo na estela do Castro de Calvos (tabela 1B).

A Pedra Formosa 2 (tabela 1A) possui uma decoração mais simples e, numa lógica atual, mais coerente. O círculo domina toda a ornamentação e também a simbólica. Quatro grupos de arcos de circunferência concêntricos, unidos por semicírculos, pequenos círculos e espirais acompanham a periferia da cavidade de entrada, contornando-a. No topo tectiforme, inscrito em dois círculos, gravou-se um tríscele, dextrorso; do lado direito, outro de menores dimensões, extrorso; do lado esquerdo, um círculo rebaixado.

Esta decoração pretende, provavelmente, reproduzir os astros: o tríscele representando o sol, no seu movimento de translação, o disco representando a lua. Reforçando esta interpretação existiria na parte externa superior esquerda uma inscrição em caracteres latinos "AVCA", que, atualmente, não conseguimos encontrar. Esta inscrição foi interpretada, como uma referência ao rio Ave que passa no sopé do monte da Citânia (Cardozo, 193132). Os símbolos utilizados no reverso deste monólito são também associados ao sol e ao calor. Trata-se de três "fossetes", uma cruz equilateral inscrita em círculo, "símbolo solar" (Cardozo, 1931-32: 255) e uma espécie de suástica flamejante geminada (de dois núcleos partem dez raios ondulantes), com muitas semelhanças com a decoração existente na trave do balneário de Santa Maria de Galegos (tabela 1A).

A pedra formosa do Castro das Eiras (tabela 1B) desperta a nossa atenção, novamente, dada a densidade da decoração que, provavelmente, também existiria na estela do povoado de Calvos.

Além do cordiforme que rematada a entrada da pedra formosa das Eiras ocorrem nos dois lados, motivos cruciformes, únicos na decoração das pedras formosas. Encimando a abertura três toros cordiformes, em baixo-relevo, dividem horizontalmente a decoração. Existem ainda outros dois relevos cordiformes, em continuidade de um dos horizontais, que dividem centralmente a estela. Tal como na Pedra Formosa 1 de Briteiros temos uma superfície decorativa dividida espaços distintos, neste caso quatro, a que acresce a zona tectiforme fragmentada. O espaço central, superior, dividido em dois, está preenchido por motivo decorativo de lanceolado ou entrelaçado triangular, como em Briteiros 1, mas invertido, tendo à esquerda três conjuntos verticais de postes ou SS duplos, simétricos entre si, que se repetem em número de dois no lado esquerdo. "Quatro fragmentos decorados, encontrados durante a escavação, pertencem, sem dúvida, à parte amputada da "pedra formosa" (Queiroga e Dinis, 2008-2009: 145). Trata-se de dois trísceles de cinco pontas, um do lado esquerdo e outro do lado direito, um girando à esquerda e outro à direita.

Fariam parte do sistema construtivo deste balneário-sauna outras pedras decoradas (cordiforme, "espinha de peixe" e dupla espiral), que foram encontradas em escavação, bem como, a pedra existente no Museu da Sociedade Martins Sarmento (tabela 1B) e atribuída ao Castelo de Vermoim (Queiroga e Dinis, 2008-2009). Esta possui uma decoração com entrelaçado triangular ou lanceolado, motivo que se repete várias vezes, na horizontal. 
Tabela 1B. Diversos elementos sobre os balneários-sauna e as pedras formosas.

\begin{tabular}{|c|c|c|c|}
\hline $\begin{array}{l}\text { DESIGNAÇÃO e } \\
\text { PROVENIÊNCIA }\end{array}$ & $\begin{array}{c}\text { PLANTA } \\
\text { SIMPLIFICADA E IMAGEM } \\
\text { DO BALNEARIO-SAUNA }\end{array}$ & $\begin{array}{l}\text { IMAGEM DA PEDRA } \\
\text { FORMOSA }\end{array}$ & $\begin{array}{l}\text { LOCALIZAÇÃO } \\
\text { ACTUAL }\end{array}$ \\
\hline $\begin{array}{l}\text { BALNEÁRIO DO } \\
\text { CASTRO DAS } \\
\text { EIRAS } \\
\text { Castro das Eiras, } \\
\text { Alto das Eiras, Vila } \\
\text { Nova de Famalicão } \\
\text { (n' } 10 \text { no mapa) }\end{array}$ & (Queiroga e Dinis, 2008-2009) & (Queiroga e Dinis, 2008-2009) & $\begin{array}{l}\text { Visitável no Castro } \\
\text { das Eiras, } \\
\text { Famalicão, mas de } \\
\text { difíil acesso. } \\
\text { A réplica, à escala, } \\
\text { elaborada para } \\
\text { exposição, em } \\
2007, \text { não é } \\
\text { actualmente } \\
\text { visitável. }\end{array}$ \\
\hline $\begin{array}{l}\text { Possivelmente } \\
\text { proveniente do } \\
\text { balneário do Castro } \\
\text { das Eiras, } \\
\text { Alto das Eiras } \\
\text { Vila Nova de } \\
\text { Famalicão } \\
\text { (n' } 10 \text { no mapa) }\end{array}$ & & (Queiroga e Dinis, 2008-2009) & $\begin{array}{l}\text { Visitável no Museu } \\
\text { da Sociedade } \\
\text { Martins Sarmento, } \\
\text { em Guimarães. } \\
\text { Referenciada como } \\
\text { proveniente do } \\
\text { Castelo de } \\
\text { Vermoim. }\end{array}$ \\
\hline $\begin{array}{l}\text { PEDRA } \\
\text { FORMOSA DO } \\
\text { CASTRO DE } \\
\text { CALVOS } \\
\text { Proveniente do Alto } \\
\text { de Quintãs, Póvoa } \\
\text { de Lanhoso } \\
\text { (n'9 no mapa) }\end{array}$ & Desconhecida. & & $\begin{array}{l}\text { Visitável na Casa } \\
\text { da Botica, Sala de } \\
\text { Interpretação do } \\
\text { Território - } \\
\text { Pátio dos Artistas, } \\
\text { Póvoa de Lanhoso. }\end{array}$ \\
\hline $\begin{array}{l}\text { BALNEÁRIO DA } \\
\text { CITÂNIA DE } \\
\text { SANFINS } \\
\text { Sanfins de Ferreira, } \\
\text { Paços de Ferreira. } \\
\text { (n } 12 \text { no mapa) }\end{array}$ & & & $\begin{array}{l}\text { Visitável na Citânia } \\
\text { de Sanfins, tendo } \\
\text { sido objecto de um } \\
\text { projecto de } \\
\text { valorização. }\end{array}$ \\
\hline $\begin{array}{l}\text { BALNEÁRIO } \\
\text { CASTREJO DO } \\
\text { FREIXO } \\
\text { Estação Romana } \\
\text { do Freixo, } \\
\text { Tongobriga, } \\
\text { Marco de } \\
\text { Canaveses. } \\
\text { (n'14 no mapa) }\end{array}$ & & & $\begin{array}{l}\text { Visitável com } \\
\text { acesso pela Área } \\
\text { Arqueológica } \\
\text { Romana do Freixo } \\
\text { - Tongobriga, } \\
\text { Marco de } \\
\text { Canaveses. } \\
\text { Situa-se ao lado } \\
\text { das termas } \\
\text { romanas. }\end{array}$ \\
\hline
\end{tabular}


Tabela 1C. Diversos elementos sobre os balneários-sauna e as pedras formosas.

\begin{tabular}{|c|c|c|c|}
\hline $\begin{array}{l}\text { DESIGNAČÃO e } \\
\text { PROVENIÊNCIA } \\
\end{array}$ & $\begin{array}{c}\text { PLANTA } \\
\text { SIMPLIFICADA E IMAGEM } \\
\text { DO BALNEARIO-SAUNA }\end{array}$ & IMAGEM DA PEDRA FORMOSA & $\begin{array}{c}\text { LOCALIZAÇÃO } \\
\text { ACTUAL }\end{array}$ \\
\hline $\begin{array}{l}\text { BALNEÁRIO DO } \\
\text { CASTRO DE } \\
\text { MAXIMINOS } \\
\text { Maximinos, } \\
\text { Braga. } \\
\text { (n'5 no mapa) }\end{array}$ & (1) & & $\begin{array}{l}\text { Visitável na } \\
\text { Estação de } \\
\text { caminhos de } \\
\text { Ferro de Braga, } \\
\text { tendo sido } \\
\text { objecto de } \\
\text { projecto de } \\
\text { valorização. }\end{array}$ \\
\hline $\begin{array}{l}\text { PEDRA } \\
\text { FORMOSA DE } \\
\text { SARDOURA } \\
\text { Castro do } \\
\text { Pedregal/Monte do } \\
\text { Castro, } \\
\text { Sardoura, Castelo } \\
\text { de Paiva. } \\
\text { (n } 13 \text { no mapa) } \\
\end{array}$ & Desconhecida. & & Desconhece-se. \\
\hline $\begin{array}{l}\text { PEDRA } \\
\text { FORMOSA DO } \\
\text { CASTRO DE } \\
\text { EIRAS. } \\
\text { Aboim das Choças } \\
\text { Arcos de Valdevez } \\
\text { ( } \mathbf{n}^{\circ} 2 \text { no mapa) }\end{array}$ & Desconhecida. & (Silva e Ferreir & $\begin{array}{l}\text { Desconhece-se } \\
\text { Esta pedra } \\
\text { formosa apenas } \\
\text { é conhecida por } \\
\text { uma imagem. }\end{array}$ \\
\hline $\begin{array}{l}\text { CASTRO DE } \\
\text { FONTALVA } \\
\text { Elvas. }\end{array}$ & Desconhecida. & (García y Bellid & $\begin{array}{l}\text { Desconhece-se. } \\
\text { Trata-se de uma } \\
\text { referência, com } \\
\text { desenho, } \\
\text { indicando } \\
\text { informação de } \\
\text { Ernesto Veiga de } \\
\text { Oliveira, de A. } \\
\text { García y Bellido } \\
\text { (1968: 21). }\end{array}$ \\
\hline $\begin{array}{l}\text { CASTRO DE } \\
\text { ARMEA (Cibdá de } \\
\text { Armeá 2) } \\
\text { Santa Mariña de } \\
\text { Augas Santas } \\
\text { Allariz, Ourense } \\
\left(\mathbf{n}^{\circ} 1 \text { no mapa) }\right.\end{array}$ & Desconhecida. & $\underbrace{(\}\}^{z}}_{\text {(Lorenzo Fernández, 1948) }}$ & $\begin{array}{l}\text { Cripta da Basílica } \\
\text { de La Ascensión } \\
\text { y Os Fornos, } \\
\text { Santa Marina das } \\
\text { Aguas Santas, } \\
\text { Allariz, } \\
\text { Ourense, Galiza. }\end{array}$ \\
\hline
\end{tabular}


A estela do Castro de Calvos apresenta-se muito incompleta e fragmentada, possuindo uma decoração muito relevada, com motivos entrelaçados curvilíneos, em forma de oito, horizontais, ladeando a entrada. Um motivo em espinha decora o rebordo lateral direito, precedido por uma decoração em entrelaçado fechado que ladeia, tal como em Briteiros 1 , o semicírculo que permitia a entrada na câmara. Vários toros lisos, muito relevados, e em posições diversas, definem diversas molduras e diversas áreas de ornamentação.

A pedra formosa do Castro de Sanfins (tabela 1B) possui apenas uma decoração sobrepujando a entrada semicircular, assemelhando-se a corda dupla, tal como a do Freixo (tabela 1B), em pedra móvel, tomando, neste último, a forma de espinha de peixe.

A estela do balneário do Castro de Eiras (tabela 1C), Arcos de Valdevez (Silva e Ferreira, 2016) apresenta uma decoração completamente diferente em termos de técnica de gravação, neste caso por fricção, muito mais ténue, sem aparente organização e de difícil interpretação. Os motivos gravados, como gravuras rupestres, desenham espirais que se unem, círculos, linhas e covinhas tendo apenas dois trísceles, dextrorsos, como elemento comum às demais.

A estela do castro de Ribalonga, Pópulo (Alijó, Vila Real), da qual não temos qualquer imagem, teria decoração "constituída por um desenho heliolátrico, com 21 raios dextróginos partindo de uma cavidade central côncava e enquadrada por um círculo externo, uma série de três círculos encadeados e um motivo em espiga na parte inferior" (Parente, 2003: 115).

Uma análise superficial permite concluir que os motivos decorativos utilizados neste tipo de balneário-sauna não obedecem aos cânones artísticos como no caso da decoração arquitetónica das cabanas (Silva, 1986a), ou mesmo das esculturas de guerreiros, dada a diversidade dos mesmos. Em Briteiros, as duas estelas possuem motivos decorativos muito diferenciados. A Pedra Formosa 1 possui um entrelaçado triangular, existente na estela de Eiras (Famalicão). Os outros elementos, com exceção dos trísceles, designadamente o quadriculado ou reticulado central não são utilizados, tal como os da Pedra Formosa 2, em qualquer outra, salvo na decoração das habitações.

O encanastrado ou entrelaçado curvilíneo apresenta-se "estilizado" na trave de Galegos de forma ondulante, representando, eventualmente, a água ou o vapor de água. Possui paralelos no que seria uma porta de uma habitação da Cividade de Âncora (Silva, 1986a), na pedra formosa do Castro das Eiras e no reverso da de Briteiros 2. O elemento cordiforme, embora com variantes, se repete nas estelas de Sanfins (em corda dupla) e do Freixo (em espinha de peixe), tal como no Castro das Eiras, em que a abertura semicircular é também ornamentada por um motivo em espinha, em baixo-relevo. A de Fontalva, Elvas, teria também o motivo cordiforme a emoldurá-la (García y Bellido, 1968), mas perdeu-se nos tempos e temos, também, dúvidas sobre a proveniência atribuída.

O paralelismo decorativo entre a estela do Alto das Eiras (Famalicão), a de Briteiros 1 e a de Calvos é grande, levando a que, de imediato, o espectador as relacione automaticamente, sobretudo no caso das duas primeiras, orientando o seu pensamento para que tenham sido feitas pelo mesmo escultor. A das Eiras demonstra um talhe de maior perfeição e associa ainda os elementos decorativos astrais (trísceles) da pedra formosa II de Briteiros.

Estas duas peças são obras ímpares, autênticos manuais da decoração arquitetónica castreja, compêndios de motivos decorativos que possibilitam, aos arqueólogos atuais ou historiadores de arte, a criação de uma tipologia com base na decoração das mesmas, passível de ser aplicada a uma parte significativa de exemplares da área castreja da parte final da Idade do Ferro do noroeste peninsular.

A decoração dos balneários sauna com pedra formosa galegos e asturianos resumese ao exemplar do Castro de Armea, que apresenta sulcos de difícil interpretação: um deles assemelha-se ao algarismo três e o outro a um ofídio. No cimo da entrada, uma cruz 
grega, de gravação posterior. Tal como M. Quintela (2016), consideramos que as pedras formosas das Astúrias, provavelmente devido à matéria-prima em que os monumentos foram elaborados, não possuem decoração.

Tabela 2. Proposta da evolução das fases de gravação de alguns motivos decorativos.

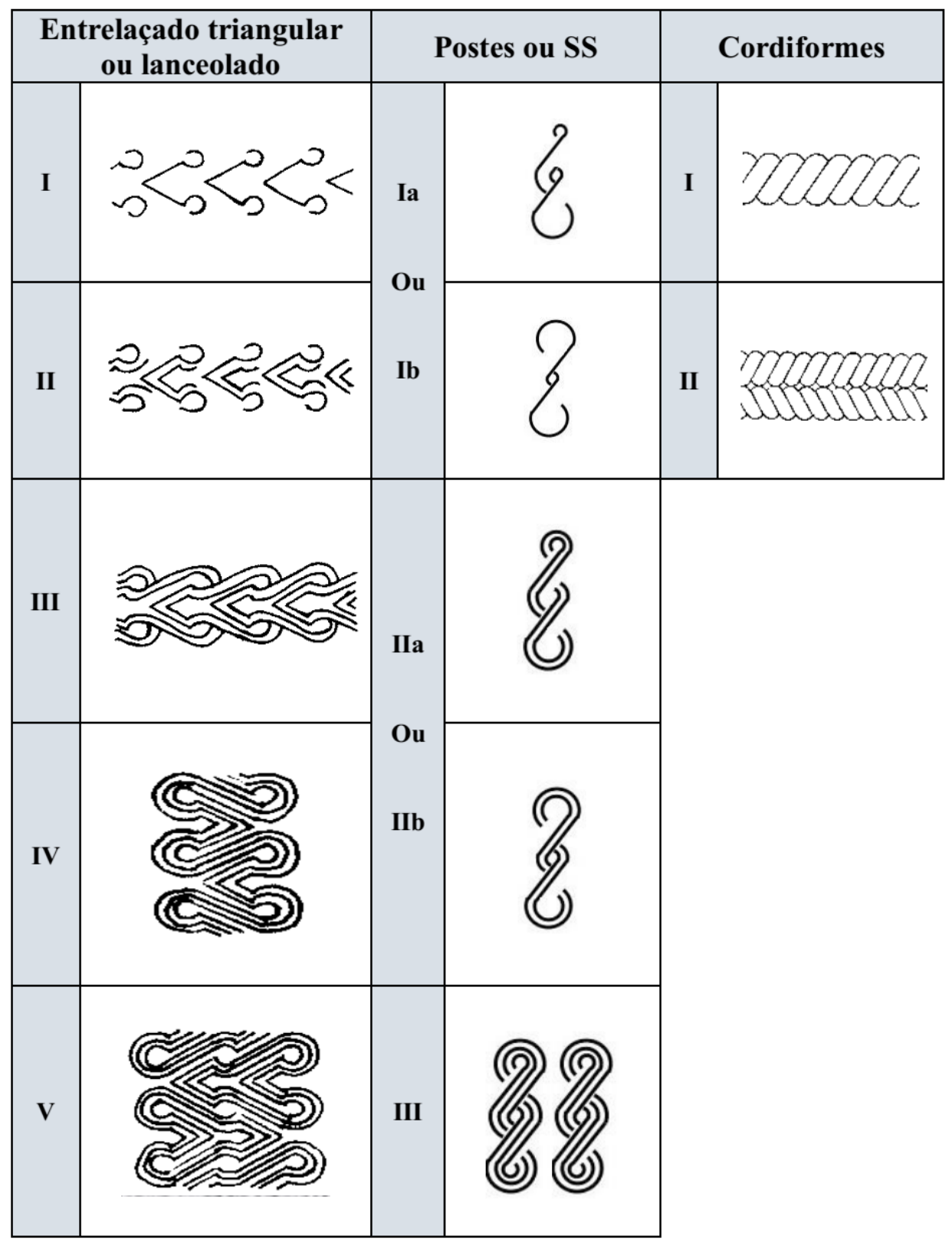

Tendo por base o apriorismo de que os atos humanos são o resultado, entre outros, da cultura, da tradição, também a elaboração destes ornatos, em pedra granítica, não são obra do acaso. Têm por base o gosto pela arte, o desejo de tornar belo, mas também são expressão da representação de elementos com carácter simbólico-religioso, inseridos no contexto sociocultural da época.

O artífice-canteiro quando extraía a pedra aos afloramentos, quando a trabalhava, conformando-a ao tamanho e formato desejado para construir habitações, arruamentos, monumentos balneários-sauna, quando a esculpia e ornamentava, decorando casas, criando belas esculturas, tornava-se no artífice-escultor que transmitia uma mensagem aos seus conterrâneos e também aos que no futuro as contemplam ou as estudam - como nós! 
Os grupos de artistas ambulantes (Almeida, 1981; Silva, 1981-82), escultores das estátuas de guerreiros, dedicavam-se também à construção civil e, em especial, à construção de balneários-sauna, formando uma espécie de associações profissionais regionais de artífices (Silva, 1986). Na Citânia de Briteiros, existiram certamente diversos escultores, como o comprova a infinidade de padieiras, ombreiras e trísceles com variados motivos ornamentais, as duas pedras formosas, entre outras peças. Estes escultores, talvez se tenham deslocado ao Castro de Sabroso, local onde a decoração com o motivo entrelaçado triangular de Briteiros ocorre em ombreiras e padieiras, ou ao castro do Alto das Eiras - são meras conjeturas.

Iconograficamente todos os motivos utilizados na decoração arquitetónica, nas pedras formosas ou nas estátuas de guerreiros galaicos são geométricos. Têm como suporte inicial o círculo ou a linha, desenvolvendo-se em diversas formas. Dado que a maioria dos motivos empregues são baseados na linha curva, o compasso seria muito utilizado, e sabe-se que este já existia nomeadamente em Briteiros (Sarmento, 1904), um dos maiores núcleos de decoração arquitetónica da Cultura Castreja.

Numa tentativa de compreender a génese da conformação de elaboração destes motivos pensamos que o escultor castrejo se terá influenciado nos entrelaçados de vime, e/ou nas cordas de fibras vegetais, transpondo-os para a gravação da pedra. Terá elaborado uma técnica relativamente simples para gravar os diversos motivos que, se os reduzirmos aos elementos iniciais, melhor podemos compreender como se formam e qual o método seguido, conforme as diversas fases que tentamos demonstrar na Tabela 2, relativamente a alguns dos motivos decorativos -o entrelaçado triangular ou lanceolado, os postes ou SS e os cordiformes-.

Eventualmente desenhavam na pedra o motivo que pretendiam elaborar, com uma gravação simples, riscando a pedra, seguindo um desenho feito previamente e iniciando o traçado do motivo do mais simples para o mais elaborado. Este tipo de técnica, depois do decalque feito sobre o original (figura 4), foi utilizado aquando da construção da réplica à escala do balneário do Castro do Alto das Eiras (figura 5), conforme fotografias a que tivemos acesso ${ }^{3}$, um exemplo ímpar de arqueologia experimental.

Figura 4. Decalque dos motivos decorativos da pedra formosa dos Castro do Alto das Eiras.

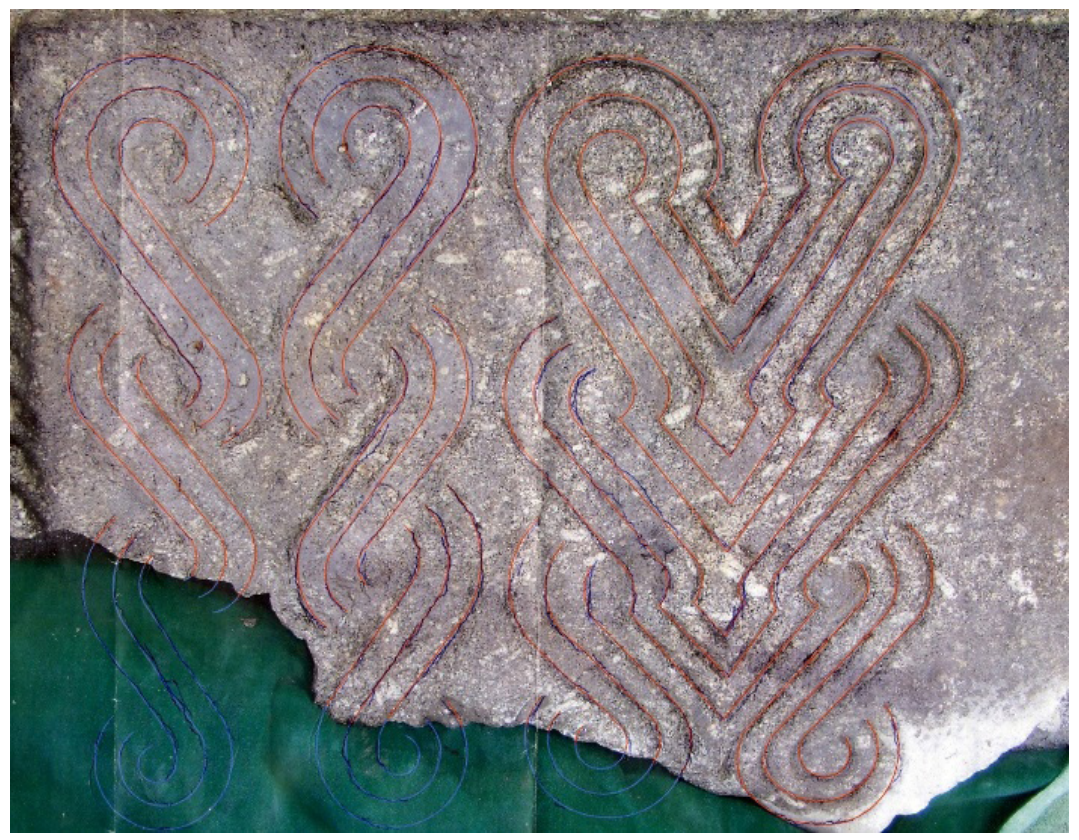

3 Agradecemos ao Dr. Paulo Varregoso a disponibilização das fotografias. 
Figura 5. Elaboração da réplica à escala da pedra formosa do Castro do Alto das Eiras.

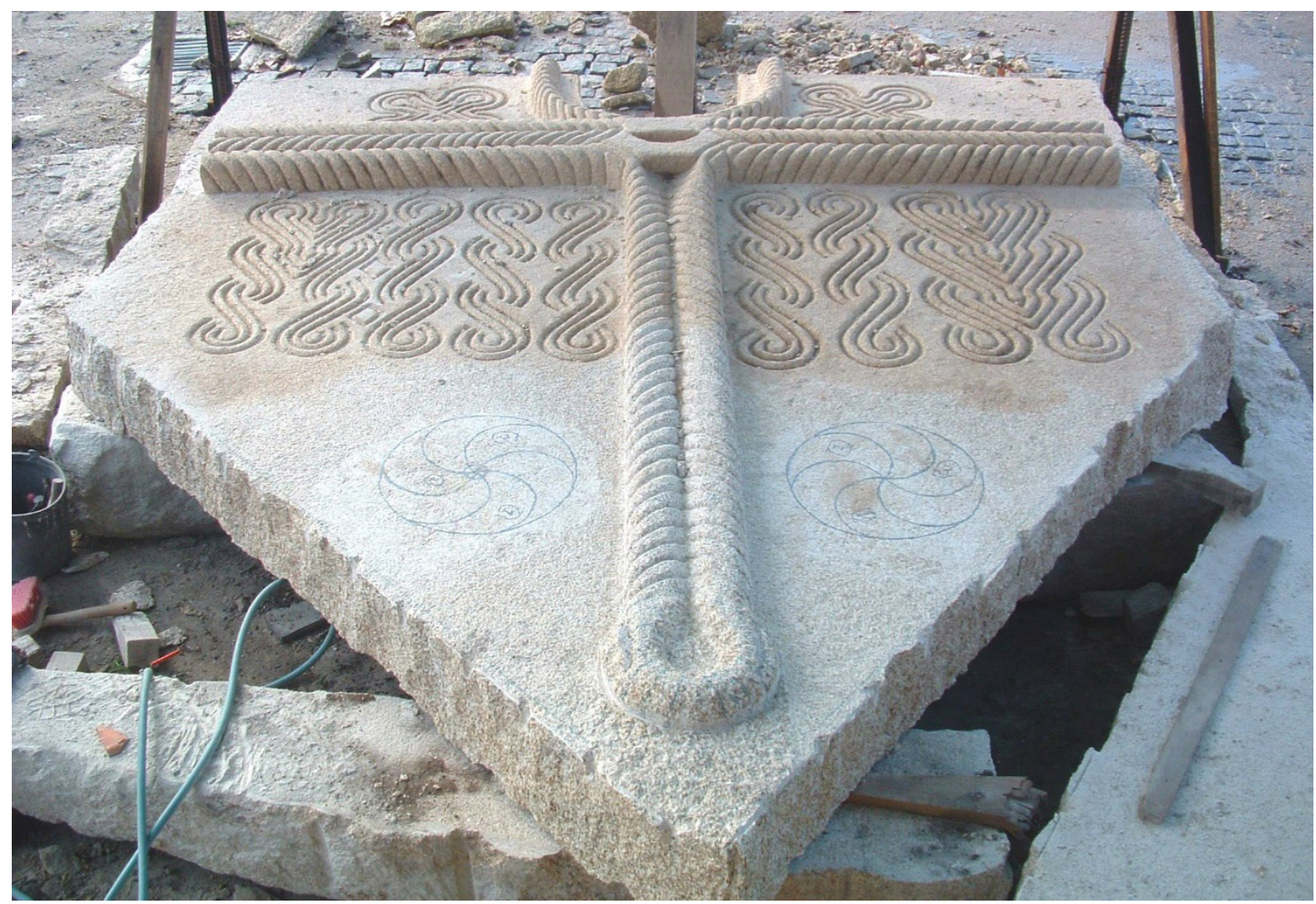

Na elaboração do entrelaçado triangular ou lanceolado -o mais utilizado na decoração das pedras formosas-, partiriam de duas linhas que se uniam em $V$ e elaboravam o desenho com uma série de linhas e semicírculos, formando as pontas das lanças, que repetiam conforme o espaço disponível. No caso dos postes ou SS iniciariam o desenho por um semicírculo associado a diversas linhas curvas, que completariam o motivo em $\mathrm{S}$. Os SS poderiam ser executados de diversas formas, pelo que sugerimos duas das formas entre as que consideramos mais plausíveis, com as referências lb e Ilb da Tabela 2.

$\mathrm{Na}$ base, sempre elementos geométricos simples, os tipos eternos de ornamentação de todos os tempos, da arte de todos os povos.

A análise dos motivos decorativos não tem sido objeto de estudos quer em termos gráficos, quer simbólicos. Contudo, recentemente García Quintela e Santos-Estévez (2015: 25 e 85) propuseram a hipótese de os motivos seguirem um modelo geométrico baseado na simetria, segundo quatro princípios: transposição, rotação, reflexão e reflexão por deslizamento. Consideram, ainda, que a decoração das pedras formosas se organizada em três secções verticais, utilizando motivos repetidamente associados a cada uma dessas secções. Contudo, este tipo de explicação apenas pode ter alguma lógica em três das estelas conhecidas (Briteiros 1, Calvos e Alto das Eiras) uma vez que nas demais os motivos não obedecem a este esquema decorativo.

Em relação à Pedra Formosa II de Briteiros, M. Santos-Estévez (2017) propõe, sem mais explicações ou qualquer evidência arqueológica ou de outro tipo de fonte, que com a decoração desta "non só certificamos o uso do pentágono regular para distribuir a decoración de Briteiros, senón que tamén se evidencia que, os artífices desta pedra formosa, quixeron deixar constancia dos seus coñecementos de xeometría na forma da decoración". 
A técnica de gravação utilizada na feitura da gramática decorativa é variada, apresentando-se sob várias formas, com mais ou menos relevo, com maior ou menor profundidade e consequentemente com maior ou menor sensação de tridimensionalidade.

A técnica do alto-relevo ou falso baixo-relevo utilizada nos diversos toros de três das pedras formosas conhecidas necessitaram de utilizar métodos já do âmbito da escultura em pedra, levando à criação pontual de motivos tridimensionais. Como mera hipótese podemos referir que a decoração arquitetónica existiria previamente em madeira, passando posteriormente, ao granito.

Os tipos de técnica de gravação utilizados apenas são possíveis após o uso sistemático do designado ferro-aço no trabalho da pedra, provavelmente na "última parte do seculo I a.C., por efeito da política de César para a Lusitânia e da conquista de Augusto..." (Almeida, 1986: 161). Aparentemente as diferenças e variações evidenciadas na técnica de gravação, de um povoado para outro, de uma pedra formosa para outra, são resultado, sobretudo, da diversidade de artífices e do gosto estético e mestria, do que de diferenças cronológicas ou de um fundo cultural diferente.

No campo da simbologia desta arte decorativa associada aos balneários-sauna podemos apenas aproximar-nos da carga simbólico-religiosa que teriam através de suposições falíveis, ainda que possívei,s uma vez que "el profundo contenido simbólico de sus manifestaciones más genuinas en las que debían consignarse mensajes compartidos de orden social, religioso o astral" (Ruibal 2006: 576). (...) sigue escapándose al entendimiento de los investigadores. La creación plástica simbólica (...) posee un "significado de relevancia social" (Carballo y Soto, 1998) que nos resulta todavía inaprensible (Villa, 2016: 103). Os trísceles e os círculos estariam de algum modo associados aos símbolos astrais, tal como o entrelaçado fechado. O fogo, presente na combustão, sendo fonte de calor e energia, estaria simbolizado em composições com base no círculo ou no entrelaçado triangular. Os cordiformes, relacionados com a força. O entrelaçado curvilíneo e outros encadeados de SS ou de círculos lembrariam a ondulação do rio, do fumo, do vapor de água, como alentos da vida. Fogo, sol e água, elementos vitais da vida e do funcionamento destes balneáriossauna. Fogo e água permitem a sauna, o banho, a purificação, e talvez a cura ou a procura da mesma, caso tivessem função medicinal. Em síntese, símbolos da vida sempre em mudança e renovação, tal como o sol fonte de calor e vida, que renasce todos os dias.

A função utilitária de balneário-sauna seria a principal, mas agregava também funções medicinais, do banho salutar e purificador, de eventual prevenção e/ou cura dos males. Igualmente a hipótese de associação a ritos iniciáticos está bem sintetizada nas palavras de Almagro-Gorbea e Lucia Moltó:

Estos baños son característicos de las poblaciones lusitano-galaicas de la cultura castreña (...) por lo que corresponde a un substrato ideológico y cultural común que representa una de las más antiguas tradiciones de baños de sudor actualmente documentadas. Pero su mayor interés radica en su evidente función ritual, coherente con lo que se va conociendo de la ideología y la sociedad castreña, ya que parece relacionada con ritos de iniciación de cofradías de guerreros características de dichas poblaciones (1992: 96).

Ainda que a representação humana, em termos de decoração arquitetónica, na cultura castreja, não seja, regra geral, representada, ocorre de outras formas (por exemplo, em baixo-relevo de Briteiros) e em gravuras rupestres da Idade do Ferro. Os motivos em relevo, toros, que dividem três das pedras formosas conhecidas, foram referidos como figura humana estilizada, de braços e pernas abertas (Cabré, 1922) e ídolo feminino esquematizado (Jordá, 1969). Estas interpretações podem levar-nos a uma leitura diferente 
da habitual. Foram também referidos como âncora (Cardozo, 1928). Qualquer das situações teria uma lógica, sobretudo a relativa à figura humana, que abraça todos os outros símbolos, organizando a distribuição dos mesmos nas referidas pedras formosas e ao mesmo tempo na cosmogonia castreja, especialmente destes balneários-sauna.

Desde tempos imemoriais que a arte, na interpretação dos diversos investigadores, das mais diversas áreas do saber, está relacionada com o culto da vida, dos mortos, com a religião, e também com a magia e seus rituais. Para documentar a religião da cultura castreja temos as fontes arqueológicas, literárias e epigráficas. Ao panteão castrejo estavam associadas divindades protetoras das diferentes comunidades, tutelares de um povoado, ao lado de deuses venerados, de um modo mais geral, pelo território de implantação geográfica da cultura castreja. Existiam ainda diferenças em relação aos deuses dos habitantes dos castros litorâneos, de interior, ou até ribeirinhos, como exemplo, deste último, refira-se a sacralidade atribuída ao rio Lima (Vasconcelos, 1913).

Esta religião consistiria numa serie de rituais festivos, rituais adivinhatórios, druidismo, sacrifícios humanos e de animais, adoração dos deuses com dádivas de oferendas, como nos apercebemos pela leitura das fontes clássicas, em especial, nas "Guerras Púnicas" de Sílvio Itálico (III, 344-345) e na "Geografia" de Estrabão (III, 3, 6 e 7).

Apesar da diversidade de divindades, as populações proto-históricas teriam a conceção de que o rei dos deuses e do mundo era o sol, luzeiro, eterno e infinito, supremo criador da vida (Santos, 1963). Ao culto heliolátrico estariam associados outros cultos dos elementos da natureza, personificados no fogo e na água, e canalizados para estes edifícios balneáriosauna que tinham necessidade vital da água e do fogo. Sabe-se da existência de deuses ligados ao culto das águas, já referidos, e, em especial, das fontes medicinais com que estes monumentos se relacionavam, assim como a sua decoração. O sol é também apresentado não como um deus, mas como "propiciador de actividades de terceira função", como ser "regenerador da natureza" (Silva, 1986: 296) moldado nas manifestações heliolátricas de que os trísceles, as espirais, entre outros motivos circulares, são expressão material. Numa perspetiva simbólico-religiosa, a suástica, materializada nos trísceles, parece-nos estar ligada a uma simbologia astral, a um culto solar (criação, fertilidade, crescimento, luz, calor, força, infinito/eternidade), numa só expressão, ao culto da vida, e à sacralização das águas com finalidades medicinais (Silva, 1987).

Os motivos decorativos das pedras formosas possuem, como referimos, elementos comuns entre eles. Podemos referir a localização espacial na estela tectiforme, sendo, por vezes, gravuras ao ar livre em que existiria acessibilidade a todos os habitantes do povoado, uma vez que o espaço de habitação e o espaço artístico coincidem. Igualmente as condições de luz e iluminação, podendo não ser as mais favoráveis, caso a antecâmara que precede o átrio possuísse cobertura, possibilitava a entrada da luz direta, do sol e, portanto, natural, dando a possibilidade de facultar a visibilidade ao grupo.

Em termos da temática representada esta possui alguma unidade, dado que os elementos se repetem de monumento para monumento, embora existam alguns motivos mais raros - há sempre exceções. Trata-se, em termos de representação, de uma arte concreta, para ser vista e apreciada de forma direta. Paralelamente é uma arte abstrata e metafórica dado que pretende, supomos nós, através de símbolos revelar uma realidade quer a consigamos apreender ou não. Por exemplo, os motivos geométricos ainda que estilizados pretendem representar possivelmente o sol e outras forças da natureza. Assim, através de um elemento abstrato consegue-se figurar um elemento comum, apropriando uma realidade. Ao mesmo tempo transmite-se uma mensagem através dos signos repletos ou não de simbolismo, gravados na pedra que, posteriormente, é interpretada e, eventualmente, compreendida. Como referiu Humberto Eco (1979: 13) "a signal is a 
pertinent unit of a system that may be an expression system ordered to a content, but could also be a physical system without any semiotic purpose (...). A signal can be a stimulus that does not mean anything but causes or elicits something".

$\mathrm{Na}$ aparente desordem haverá uma ordem! A junção de motivos conduz à apreensão possível do tema e, desta forma, do argumento que está por trás da figuração representada.

Contudo, de um ponto de vista geral, dado que não se passa o mesmo com todos os motivos, a compreensão é independente e posterior à representação, uma vez que a figuração é simbólica e não naturalista. Não permite uma leitura rápida e concreta a todos os recetores dos ícones. Talvez só alguns tivessem acesso à interpretação dos mesmos!

Se se trata de uma arte exposta, de certa forma, ao ar livre, com provável luz natural, para desta forma ser vista por todos, deveria transmitir uma mensagem também compreendida por todos! Mas poderá ser uma arte, por hipótese, para uma elite (não fosse esta uma sociedade hierarquizada), dado que apesar de querer transmitir uma mensagem simples e concreta, não o faz de forma direta e acessível a todos. A mensagem, eventualmente, não seria recebida por todos os recetores, pois nem todos estariam integrados no contexto e na linguagem.

A representação é, em termos gerais, bidimensional. A perspetiva é fornecida raras vezes pelo relevo dos toros e cordiformes. A dificuldade do trabalho da pedra não facilitaria a sensação tridimensional que também poderia não ser um objetivo.

Recorrendo também à interpretação semiótica (Eco, 1972, 1988; Trabant, 1980) podemos dizer que estamos na presença de dois discursos. Um deles é objetivo e simples. É aquele em que os motivos decorativos valem por si próprios, como significantes que representam uma arte. O outro, é um discurso extraordinariamente subjetivo, metafórico, de grande dificuldade, desconstrução e interpretação, e em que os ícones valem pelo seu significado. Existem várias realidades a constatar, ou seja, o que é visto e o que é interpretado. Conforme o que se vê, a interpretação, o significado, será diferente.

Imaginemos, então, esta situação: a decoração das pedras formosas como um discurso visual, em que o emissor é o ícone gravado, por um ser desconhecido, em uma época cronologicamente distante (ainda que conhecida), e o recetor foi o habitante do povoado castrejo, mas, transpondo para os dias de hoje, é o arqueólogo, que terá ainda mais dificuldades de interpretação. Este, o arqueólogo, tentará decifrar uma mensagem iconográfica que Ihe chega através de um canal concreto, a pedra. Contudo, vários são os elementos que escapam a este recetor. Em primeiro lugar, ele está fora do contexto, ou seja, não consegue inteirar-se completamente da realidade mental, cultural, simbólica, religiosa, cultural em que se insere a mensagem. Ora essa falta de conhecimento do contexto é só por si um ruído à boa captação da mensagem. Mas existem ainda outros ruídos, por exemplo, e entre outros, a deterioração dos signos icónicos, a estilização, as influências culturais contemporâneas, que o levam (ao arqueólogo) a fazer analogias e interpretações erróneas, transplantadas para a realidade atual.

A representação artística não é um simple formalismo exposto à nossa atenção, mas implica uma função, a qual tem sentido e significado dentro da estrutura em que está integrada (Jordá, 1983). Como refere Ángel Villa Valdés, com o qual concordamos, "el extenso repertorio de motivos gráficos y las tramas en que éstos se combinaron durante siglos cumplieran la función de marcador comunitario, de código iconográfico mediante el cual el individuo, su grupo, su territorio, se reconocían y eran reconocidos socialmente" (2016: 106).

A decoração arquitetónica castreja como forma de expressão é um veículo da expressão gráfica de objetos ou seres e é o expoente de todo aquele que pelo seu carácter indizível, inexplicável ou inexpressável pertence à categoria do simbólico inserido num tempo e num espaço, consigamos ou não a compreender. Simbolismo esse que a determinada altura se 
terá alterado, perdendo a sua função primordial e o possível carácter religioso. A situação mais curiosa prende-se com o balneário-sauna do Freixo (Marco de Canaveses) que não terá tido nenhuma influência romana na sua construção, uma vez que existe ao lado o balneário termal romano, datado do séc. I d. C. O castrejo terá sido utilizado até meados do séc. I d. C. (Dias, 1997) e continuou em funções, não sendo substituído pelo romano, contudo passou a ter outra função, no caso a de arrecadação.

\section{CONSIDERAÇÕES FINAIS}

Tivemos como um dos objetivos principais divulgar, relembrando, um património arqueológico pouco conhecido e passível de ser visitado por tantos quantos por ele se interessem. Podemos referir que a importância destes monumentos tem sido reconhecida e realçada através de uma política de conservação, restauro e valorização de que alguns destes balneários têm sido alvo, a necessitar embora de uma melhor manutenção dos projetos desenvolvidos nas estações arqueológicas a cargo de diversos organismos.

Foi, inclusivamente como já referimos, construída uma réplica, à escala, do balneário do castro do Alto das Eiras (Famalicão) para exposição, já em 2007, no Museu Nacional de Arqueologia (Silva, 2007; Silva, Oliveira e Lobato, 2010-11), atualmente desmontada e armazenada, aguardando pelo centro interpretativo de balneário do castro das Eiras, já projetado e a ser construídos (assim se espera) em Famalicão. Esta réplica, sendo uma reconstrução do passado, foi um projeto de grande envergadura que necessita, a nosso ver, de ser dignificado, bem como todos dos balneários-sauna percursores do termalismo da península Ibérica e dos diversos tratamentos de hidroterapia, balneoterapia, entre outros, hoje tão em voga em diversos roteiros turísticos e medicinais.

A sistematização do conhecimento atual sobre as pedras formosas e os seus motivos decorativos, inseridas na estrutura arquitetónica dos balneários-sauna julgamos também ter sido conseguida. Nos quadros que apresentamos sistematizamos, dentro do possível, as plantas dos monumentos (publicadas por diversos autores), e o levantamento dos motivos decorativos das pedras formosas, dando indicações sobre os locais de achamento e de atual visitação.

A arquitetura destes monumentos organizava-se estruturalmente de forma a possibilitar banhos de água fria, no exterior e banhos de tipo sauna, no interior. As duas áreas são divididas pela estela conhecida por pedra formosa que separa uma zona da outra, permitindo a entrada por uma pequena abertura em semicírculo, a todos aqueles que tivessem essa possibilidade - todos ou apenas alguns? Homens ou mulheres, ou, ainda, os dois? Jovens, como forma de concretização de ritos iniciáticos, e/ou adultos? Ou, de qualquer idade? Fica-nos, pois, muitas dúvidas, que dificilmente terão algum dia resposta!

Conforme referimos, a pequena abertura de entrada existente na pedra formosa que dava acesso à câmara onde se realizava o banho-sauna, limitava o acesso e utilização a pessoas com um porte relativamente delgado e ágil. Trata-se de uma das razões porque nos questionamos sobre quem usufruía destas saunas. A entrada apenas seria possível a pessoas com agilidade suficiente para aceder a um espaço exíguo e de muito difícil acesso! Os rituais iniciáticos de jovens, delgados, não ficavam excluídos, mas as pessoas com algum problema de mobilidade teriam muitas dificuldades, e as que possuíssem uma estrutura física robusta ficavam de todo impossibilitadas de entrar.

No que concerne às leituras sobre a interpretação da decoração das pedras formosas (elemento material), de forma a tentar conhecer o seu simbolismo (elemento imaterial) apresentamos diversas hipóteses, muito relacionadas com os elementos da natureza, designadamente com o sol e a água, mas que também continuam a ser leituras possíveis, prováveis, mas não definitivas. 
Essa análise simbólica foi feita com base ao recurso da pouca bibliografia existente sobre a temática em estudo e nas nossas inferências. Recorremos, ainda, a uma interpretação interdisciplinar através da semiótica (ou semiologia), como ciência de interpretação dos signos e sinais de comunicação, apresentando, essencialmente propostas, que pretendem aclarar ideias desmontando as mensagens implícitas nos motivos decorativo-simbólicos.

A desconstrução dos símbolos conforme a Tabela 2 não nos permitiu chegar mais perto da sua interpretação e da compreensão do que na realidade os mesmos nos querem transmitir, apenas que os elementos curvos são dominantes e que são expressão da cultura de um povo e de uma época.

Apesar das diversas leituras possíveis apontadas, mantem-se muitas dúvidas relativamente à interpretação simbólica da funcionalidade destes balneários-sauna, associada à interpretação simbólico-religiosa dos elementos decorativos, dada a dificuldade de conhecimento da realidade, da qual apenas nos conseguimos aproximar.

Ficamos, sim com a perceção de que estes monumentos teriam uma grande importância para a sociedade castreja dos finais da Idade do Ferro do noroeste peninsular, desde logo, pela dificuldade de construção dos mesmos e o gosto por os decorar como obras únicas que eram. Teriam, certamente, uma função cultural e social no seio das diversas comunidades castrejas onde estavam inseridos, procurando representar elementos vitais à sobrevivência. Representação essa para a qual apontamos algumas leituras: função espiritual, função religiosa, através da gestão de elementos vitais: sol, água, fogo. Um simbolismo fulcral no seu quotidiano que não conseguimos compreender na totalidade, mas que nos consegue impressionar com uma arte que tanto tem de belo e simples como de rude e imponente.

\section{BIBLIOGRAFIA}

Almagro-Gorbea, M. e Álvarez Sanchís, J. R. (1993), "La 'sauna' de Ulaca: saunas y baños iniciáticos en el mundo céltico", Cuadernos de Arqueología de la Universidad de Navarra, 1, pp. 177-232.

Almagro-Gorbea, M. e Moltó, L. (1992), "Saunas en la Hispania prerromana", Espacio, Tempo y Forma, 3 (5), pp. 67-102.

Almeida, C.A.F. (1974), "O monumento com forno de Sanfins e as escavações de 1973", III Congresso Nacional de Arqueologia, pp. 149-172.

- (1983), "O Castrejo sob o domínio romano. A sua transformação", Estudos de Cultura Castrexa e de Historia Antiga da Galícia, pp. 187-198.

- (1986), "Arte Castreja. A sua lição para os fenómenos de assimilação e resistência a Romanidade", Arqueologia, 13, pp. 161-172.

Araújo, J. R. (1920), Perosinho: Apontamentos para a sua monografia, Porto.

Azevedo, A. (1946), "O "Monumento Funerário" da Citânia (Nova interpretação)", Revista de Guimarães, 56 (1-2), pp. 150-164.

Berrocal Rangel, L., Martínez Seco, P. e Ruíz Triviño, C. (2002), El Castiellu de Llagú, Madrid.

Bosch Gimpera, P. (1921), "Los Celtas y la civilización celtica en la Península Ibérica", Boletin de la Sociedad Española de Excursiones, 29, pp. 248-300.

Cabré, J. (1922), "Una nueva hipótesis acerca de "Pedra Formosa" de la Citania de Sabroso (sic)", Sociedad Espanhola de Antropologia, Etnografía y Prehistoria, 1, pp. 56-71.

Calo Lourido, F. (1983), "Arte, Decoracion, Simbolismo e outros elementos da Cultura material Castrexa, ensaio de síntese", Estudos de Cultura Castrexa e de História Antiga de Galicia, pp. 159-185.

- (1993), A cultura castrexa, Vigo. 
Carballo Arceo, L. X. e Soto Arias, P. (1998), "A escultura xeométrica castrexa”, Historia da Arte Galega I. A Nosa Terra. Vigo, pp. 161-176.

Cardozo, M. (1928), "A Pedra Formosa”, Revista de Guimarães, 38, 1-2, 139-152; 39,1-2, pp. 87-102.

- (1931-1932), "Aúltima descoberta arqueológica na Citânia de Briteiros e a interpretação da 'Pedra Formosa', Revista de Guimarães, 41 (1-2), 55-60; 41 (3), 201-209; 41 (4), 250-260; 42 (1-2); 1932, 7 -25; 42 (3-4), pp. 127-139.

- (1934), "A Pedra Formosa da Citânia de Briteiros e a sua interpretação arqueológica", Brotéria, 18, 3, 30-43.

- (1946), "O 'monumento funerário’ da Citânia”, Revista de Guimarães, 56 (3-4), pp. 289-308.

Cardozo, M. (1949), "Nova estela funerária do tipo da 'Pedra Formosa”, Revista de Guimarães, 59 (34), pp. 487-516.

Cartailhac, E. (1886), Ages préhistoriques de 1'Espagne et du Portugal, Paris.

Chamoso Lamas, M. (1955), "Santa Mariña de Aguas Santas (Orense)", Cuadernos de Estudios Gallegos, 10 (30), pp. 41-88.

Conde Valvis, F. (1955), "Las termas romanas de la 'Cibdá' de Armea en Santa Marina de Aguas Santas", III Congreso Arqueologico Nacional, pp. 432-446.

Craesbeck, F. (1726), Memorias ressuscitadas da Província de Entre-Douro-e-Minho, Manuscrito da Biblioteca Nacional de Lisboa, 217 do Núcleo Geral.

Dias, L. A. T. (1997), Tongóbriga, Lisboa.

Dinis, A. P. (2002), "O balneário do Alto de Quintãs (Póvoa de Lanhoso, Norte de Portugal). Um novo caso a juntar ao livro negro da arqueologia de Entre-Douro-e-Minho", Mínia, $3^{\text {a }}$ Série, 10, pp. 159-179.

Dechelette, J. (1909), "Essai sur la chronologie de la Péninsule Ibérique", Revue Archéologique, 13, pp. 26-36.

Eco, H. (1972), "Semiologia de los mensajes visuales", Análises de las imagenes, pp. 23-80.

- (1988), O Signo, Labor.

- (1979), A Theory of Semiotics, Indiana University Press, Bloomington.

Estrabón (1965), Livro III Da Geografia, Amphitheatrvm, IX, Porto.

Fernández Fuster, L. (1953), "Sobre la interpretación de los monumentos con 'pedras formosas”", Archivo Español de Arqueología, 26 (88), pp. 379-384.

Ferreira, E. Veiga (1966), "Uma estela do tipo Pedra Formosa encontrada no Castro de Fontalva (Elvas)", Revista de Guimarães, 76, pp- 359-363.

Fernández Vega, P. A., Mantecón Callejo, L., Callejo Gómez, J. y Bolado del Castillo, R. (2014), "La sauna de la Segunda edad del Hierro del oppidum de Monte Ornedo (Cantabria, España)", Munibe, 65, pp. 177-195.

García Quintela, M. V. e Santos-Estévez M. (2015), "Iron Age saunas of northern Portugal: state of the art and research perspectives", Oxford Journal of Archaeology, 34(1), pp. 67-95.

García Quintela, M. V. (2016), "Sobre las saunas de la Edad del Hierro en la Península ibérica: novedades, tipologías e interpretaciones", Complutum, 27 (1), pp. 109-130.

García y Bellido, A. (1931), "Las relaciones entre el Arte etrusca y el ibérico", Archivo Español de Arte y Arqueología, 7, pp. 119-148.

- (1940), "El castro de Coaña (Asturias) y algunas notas sobre el posible origen de esta cultura". Revista de Guimarães, 50(3-4), pp. 284-311.

- (1968), "Las cámaras funerarias de la cultura castreña", Archivo Español de Arqueología, 41, pp. 16-44. 
Gómez Tabanera, J. M., La caza en la Prehistoria, Madrid, Istmo, 1980.

González Ruibal, A. (2006), "Galaicos. Poder y comunidad en el Noroeste de la península Ibérica (1200 a.C.-50 d.C.)". Brigantium, 18, A Coruña.

Höck, M. (1984), "Acerca dos elementos arquitectónicos decorados de castros do noroeste peninsular", Revista Guimarães, 94, pp. 389-405.

Hübner, E. (1879), "Citania”, Dispersos, pp. 445-462.

Jordá Cerdá, F. (1969), Guía del Castrillón de Coaña. Salamanca, 8-12.

- (1983), "Introducción a los problemas del arte esquemático de la Península Ibérica", Zephyrvs, 36, pp. 7-12.

Júnior, J. R. S. (1966), "Dois fornos do povo em Trás-os-Montes", Trabalhos de Antropologia e Etnologia, 1-2, 20, pp. 119-146.

Lemos, F. S., Leite, J. M. F., Bettencourt, A. M. S. e Azevedo, M. (2003), "O balneário préromano de Braga", Al-madan, II série, 12, pp. 43-46.

López Cuevillas, F. (1953), La civilización celtica en Galicia, Compostela.

Lorenzo Fernández, J. (1948), "El monumento proto-histórico de Águas Santas y los ritos funerarios de los castros", Cuadernos de Estudios Gallegos, 2 (10), pp. 157-211.

Martin, H. (1881), "La Citania de Briteiros", Revue Archéologique, 42, pp. 160-164.

Monteagudo, L. (1952), "Monumentos propiedad de la Sociedad Martins Sarmento", Archivo Español de Arqueología, 25 (85), pp. 112-116.

Moreira, A. B. (2013), "O Balneário Castrejo do Monte Padrão, Santo Tirso", Santo Tirso Arqueológico, 5, pp. 7-36.

Parente, J. (2003), O Castro de S. Bento (concelho de Vila Real) e o seu ambiente arqueológico. Vila Real.

Queiroga, F. e Dinis, A. (2008-2009), "O Balneário Castrejo do Castro das Eiras”, Portugália, 39-40, pp. 139-152.

Ramil, G. E. (1995-96), "O monumento com forno do Castro dos Prados-Espasante (Ortigueira, A Coruña) Memoria de investigação", Brigantium, 9, pp. 13-60.

Ribeiro, F. (1930-34), "Novas descobertas arqueológicas na Citânia de Briteiros", Revista de Guimarães, 40 (3-4), 171-175; 44 (3-4), pp. 205-208.

Ríos González, S. (2000), "Consideraciones funcionales y tipológicas en torno a los baños castreños del NO. de la Península Ibérica", Gallaecia, 19, pp. 93-124.

Romero Masiá, A. (1976), El habitat castreño, Santiago de Compostela.

Santa-Olalla, J. (1932), "Las estelas funerarias en forma de casa en España", Revista Investigación y Progreso, 10, pp. 182-193.

Santos-Estévez, M. (2017), "Pitágoras na Gallaecia", http://www.gciencia.com/author/ manuel-santos-estevezl [Consulta: 12-09-2017].

Santos, J. N. (1963), "Serpentes geminadas em suástica e figurações serpentiformes do Castro de Guifões", Lucerna, pp. 120-140.

Sarmento, F. M. (1888), "Antigualhas", Revista de Guimarães, 5, p. 150.

- (1881), "Expedição Cientifica a Serra da Estrela", Dispersos, 1933, pp. 127-152.

- (1899), "A arte micénica no Noroeste de Espanha", Portugália, 1, pp. 431-442.

- (1904), "Materiaes para a Archeologia do Concelho de Guimarães", Revista de Guimarães, 31.

Silva, J. N. (1876), "Esculptura Romana conhecida pelo nome de Pedra Formosa achada em Portugal, e o que ella representa", Boletim Real Associação dos Architectos Civis e Archeologos Portugueses, 9, 2.

Silva, A. C. F. (1981-82), "Novos dados sobre a organização social castreja", Portugália, Nova Série, 2-3, pp. 83-96.

- (1983), Citânia de Sanfins (Paços de Ferreira). Paços de Ferreira. 
- (1983-84), "A cultura castreja no Noroeste de Portugal: habitat e cronologias", Portugalia, Nova Série, 3-4, pp. 121-129.

- (1986), A cultura castreja no Noroeste de Portugal, Paços de Ferreira.

- (2007), "Pedra formosa: arqueologia experimental", MNA/CMVNF, Vila Nova de Famalicão).

Silva, A. C. F. e Maciel, T. (2004), "Balneários castrejos do noroeste peninsular. Notícia de um novo monumento do Castro de Roques", Portugália, Nova Série, 25, pp. 115-131.

Silva, A. C. F., Oliveira, J. e Lobato, R. (2010-11), "Balneários Castrejos: Do Primeiro Registo à Arqueologia Experimental", Boletim Cultural Câmara Municipal de Vila Nova de Famalicão, III série, 6/7, pp. 79-87.

Silva, A. C. F., Ferreira, J. S. (2016), "O Balneário Castrejo do Castro de Eiras/Aboim das Choças (Arcos de Valdevez): notícia do achado e ensaio interpretativo", Al-Madan, II Série, 20, pp. 27-34.

Silva, M. F. M. (1986a), "Subsídios para o estudo da Arte Castreja-Arte Decorativa Arquitectónica", Revista de Ciências Históricas, 1, pp. 31-68.

- (1987), "Subsídios para o estudo da Arte Castreja-Arte Decorativa Arquitectónica-II", Revista de Ciências Históricas, 2, pp. 124-147.

- (1988), Subsídios para o Estudo da Arte Castreja. A cultura dos Berrões: ensaio de Síntese", Revista de Ciências Históricas, 3, pp. 57-93.

- (2017), "Os primórdios do Termalismo: os balneários castrejos e o seu potencial turístico", Tourism and Hospitality International Journal, 9(2), pp. 4-28.

Trabant, J. (1980), Elementos de Semiótica, Editorial Presença, Lisboa.

Tranoy, A. (1981), La Galice romaine. Recherches sur le Nord-Ouest de la Péninsule Ibérique dans l'Antiquité, Paris.

Uría Ríu, J. (1941), "Excavaciones en el Castellón de Coaña", Revista de la Universidad de Oviedo, 2, pp. 85-114.

Vasconcelos, J. L. (1913), Religiões da Lusitânia, 3, Lisboa.

Villa Valdés, A. (1999), "Castro del Chao Samartín (Grandas de Salime)", Excavaciones arqueológicas en Asturias, 1995-1998, 4, pp. 11-123.

- (2000), "Saunas castreñas en Asturias", Termas romanas en el Occident del Imperio, pp. 97-114.

- (2012), "Santuarios urbanos en la Protohistoria cantábrica: algunas consideraciones sobre el significado y función de las saunas castreñas", Boletín del Real Instituto de Estudios Asturianos, 177, pp. 65-102.

- (2016), "Laberintos en cruz, lacería, sogueado y otros patrones geométricos en la plástica de la Edad del Hierro de Asturias y su pervivencia en época romana", Arqueología y Prehistoria del Interior Peninsular, 05, pp. 96-109.

Villa Valdés, Á., Menéndez Granda, A., Fanjul Mosteirin, J. A. (2007), "Excavaciones arqueológicas en el poblado fortificado de Os Castros, en Taramundi", Excavaciones Arqueológicas en Asturias 1999-2002, pp. 267-275. 